\title{
Immunoglobulin and non-immunoglobulin components of human milk inhibit Clostridium difficile toxin A-receptor binding
}

\author{
R. D. ROLFE and W. SONG
}

Department of Microbiology and Immunology, School of Medicine, Texas Tech University Health Sciences Center, Lubbock, Texas 79430, USA

\begin{abstract}
Summary. Clostridium difficile is isolated from the intestinal tracts of $>50 \%$ of healthy infants. The mechanism by which intestinal colonisation of infants by toxigenic $C$. difficile is generally asymptomatic is unknown but may reflect the presence in human milk of neutralising activity against $C$. difficile toxin A. On this basis, the ability of human milk to inhibit the binding of toxin $A$ to a purified hamster brush border membrane receptor was determined. Ten milk samples from healthy volunteers in various stages of lactation inhibited the binding of toxin A to the receptor by an average of $90 \%$. Heating and dialysis did not significantly alter the inhibitory activity of any of the milk samples. Human milk protected adult hamsters against a lethal challenge with toxin $\mathrm{A}$ but had no effect on the cytotoxic activity of the toxin. SDS-PAGE and ligand blot analyses showed that there were at least four distinct factors in human milk that specifically bound toxin A. Thiophilic adsorption chromatography was used to separate immunoglobulin from non-immunoglobulin components of human milk. IgA was the only immunoglobulin detected in human milk and $>90 \%$ of this immunoglobulin was recovered after purification by thiophilic adsorption. Both the unbound non-immunoglobulin and bound immunoglobulin fractions of human milk inhibited the binding of toxin A to the purified receptor. These results suggest that human milk may be important in protecting infants against $C$. difficile-associated intestinal disease.
\end{abstract}

\section{Introduction}

Clostridium difficile-induced antibiotic-associated intestinal disease is toxin mediated. Pathogenic strains of $C$. difficile produce two protein exotoxins: toxin A, an enterotoxin, and toxin B, a cytotoxin. These two toxins are antigenically, physically and biologically distinct. ${ }^{1,2}$ Toxin A, a 308-kDa protein, is believed to cause both the diarrhoea and the destruction of the colonic mucosa which is characteristic of intestinal disease caused by $C$. difficile. ${ }^{2,3}$ Toxin B appears to have no effect on undisturbed colonic mucosa. ${ }^{3,4}$

During the last few years investigators have noted that enteric disease does not develop in all individuals who harbour toxigenic $C$. difficile and cytotoxin in their intestinal tracts. In adults, intestinal colonisation with $C$. difficile frequently leads to disease ranging in severity from a mild, self-limiting diarrhoea to a life-threatening fulminant pseudomembranous colitis

Received 23 May 1994; accepted 10 July 1994.
(PMC). ${ }^{5,6}$ On the other hand, $C$. difficile has been isolated from the faeces of $>50 \%$ of healthy neonates and infants under 2 years of age. ${ }^{-9}$ Although there are some reports of $C$. difficile disease in infants, this is frequently associated with some debilitating condition. ${ }^{10,11}$ Carrier rates for $C$. difficile fall sharply after 1 year of age, although in the second year they are still significantly higher than the average $2 \%$ carrier rate in healthy adults. ${ }^{8,9}$ Concentrations of $C$. difficile and toxins $A$ and $B$ in the faeces of healthy infants are frequently similar to concentrations found in the intestinal tracts of adults with clinical manifestations of $C$. difficile-associated intestinal disease. ${ }^{7-9,12}$

It has been suggested that asymptomatic $C$. difficile colonisation of infants may reflect the presence of neutralising activity in human milk against $C$. difficile toxin $\mathrm{A}^{9,11}$ Human milk may protect against $C$. difficile colitis by inhibiting the binding of toxin $\mathrm{A}$ to its intestinal epithelial receptor. The binding of toxin $A$ to specific intestinal brush border receptors is undoubtedly one of the initial events in toxin A-mediated 
colitis. Numerous studies have shown that human milk protects the neonatal gastrointestinal tract against various diseases caused by infectious agents such as Salmonella and Shigella spp., Vibrio cholerae, Escherichia coli, poliovirus and rotavirus. ${ }^{13-18}$ The protective capacity of milk is based on various immunological and non-immunological factors. ${ }^{19} \mathrm{Im}$ munological factors in human milk which may protect against enteric pathogens include immunoglobulins (predominately IgA) and other factors such as lysozyme, lactoferrin, the lactoperoxidase system, and cellular components (macrophages and lymphocytes). Antibodies against toxin A in human milk may protect against $C$. difficile-associated intestinal disease by inhibiting or modifying the binding of toxin $A$ to its intestinal receptor, thereby preventing its toxic activity. Protection by human milk can also be ascribed to non-immunological components such as glycolipids, glycoproteins and free oligosaccharides. ${ }^{20-24}$ These components may function as structural analogues of cell membrane toxin $A$ receptors and competitively inhibit toxin A binding to its intestinal target receptor.

Therefore, these investigations were designed to characterise the ability of whole human milk, and the immunoglobulin and non-immunoglobulin components of human milk, to inhibit toxin A binding to an intestinal brush border membrane receptor.

\section{Materials and methods}

\section{Purification and radiolabelling of $C$. difficile toxin $A$}

C. difficile toxin A was purified from Brain Heart Infusion Broth (BBL Microbiology Systems, Cockeysville, MD, USA) filtrates of dialysis-bag cultures of a highly toxigenic strain of $C$. difficile (VPI strain 10463; Department of Anaerobic Microbiology, Virginia Polytechnic Institute and State University, Blacksburg, VA, USA) by previously described techniques. ${ }^{3,25}$

Purified toxin A was radiolabelled enzymically by the Enzymobead lactoperoxidase-glucose oxidase (BioRad Laboratories, Richmond, CA, USA) method. ${ }^{26}$ The average specific activity for radiolabelled toxin A was $4 \times 10^{6} \mathrm{cpm} / \mu \mathrm{g}$. Radiolabelled toxin A retained $>90 \%$ of its biological activity as demonstrated by cytotoxicity in HeLa tissue culture cells, mouse lethality (after intraperitoneal inoculation), hamster lethality (after intraperitoneal inoculation) and induction of hamster ileocaecitis (after intracaecal inoculation). ${ }^{26}$

\section{Purification of the hamster brush border membrane receptor for toxin $A$}

Brush border membranes (BBMs) were prepared from the small intestines of 7-day-old hamsters according to methods described previously. ${ }^{26}$ The degree of purification of the BBMs was evaluated morphologically by examination under phase-contrast microscopy and biochemically by comparing the specific activities of sucrase, lactase and alkaline phosphatase with those activities in the initial homogenate. ${ }^{26} \mathrm{~A}$ toxin A receptor was purified from the isolated infant hamsters BBMs by a combination of Triton X-114 extraction and affinity chromatography. ${ }^{27}$

\section{Binding of toxin $A$ to the brush border membrane receptor}

Specific binding of toxin A to the BBM receptor was monitored by measuring the amount of $\left[{ }^{125} \mathrm{I}\right]$ toxin $A$ bound to the receptor absorbed to plastic wells of microtitration plates (Immunolon II; Dynatech Laboratories, Inc., Alexandria, VA, USA). ${ }^{27}$

\section{Human milk}

Human milk was obtained from healthy volunteers in various stages of lactation, who were not taking antibiotics or other medication at the time of donation. The milk was centrifuged $\left(10000 \mathrm{~g}\right.$ for $15 \mathrm{~min}$ at $\left.4^{\circ} \mathrm{C}\right)$ and the clear middle layer was separated from the upper and lower layers, which contained fat and cells, respectively. The middle layer was passed through a membrane filter (pore size, $0.45 \mu \mathrm{m}$ ) to remove residual cells and fat. Filtrates were dialysed against $0.05 \mathrm{M}$ Tris- $\mathrm{HCl}$ buffer, $\mathrm{pH} 7.5$, containing $0.05 \mathrm{M} \mathrm{NaCl}$ (Tris$\mathrm{HCl}$ buffer) and stored at $-20^{\circ} \mathrm{C}$. In some experiments, the milk from 10 individuals was pooled and then centrifuged, membrane filtered and dialysed as described above.

Inhibition by human milk of toxin A binding was determined by diluting milk in Tris- $\mathrm{HCl}$ buffer. The diluted milk was then mixed with an equal volume of $\left[{ }^{125} \mathrm{I}\right]$ toxin $\mathrm{A}(500 \mathrm{ng} / \mathrm{ml})$ and incubated for $2 \mathrm{~h}$ at room temperature. The human milk-toxin A mixture was then assayed for toxin A binding activity in the microtitration well binding assay.

\section{Characterisation of the inhibitory activity against toxin A binding}

Heat stability. For tests of heat stability, dialysed fractions of human milk were diluted 1 in 4 in Tris- $\mathrm{HCl}$ buffer and heated for $5 \mathrm{~min}$ at $100^{\circ} \mathrm{C}$. After heating, the samples were examined for inhibitory activity against toxin $\mathrm{A}$ binding as described above.

Ultrafiltration. For estimation of the size of the inhibitory factors, a 1 in 4 dilution of pooled human milk in Tris-HCl buffer was subjected to positive pressure ultrafiltration in a concentrator (Amicon Corporation, Danvers, MA, USA) with a $100-\mathrm{kDa}$ cut-off membrane. The volumes of the retentate $(>100 \mathrm{kDa})$ and filtrate $(<100 \mathrm{kDa})$ were adjusted to the volume of the initial milk sample with Tris$\mathrm{HCl}$ buffer.

Gel filtration. Ascending chromatography, per- 
formed in a column $(2.0 \times 20 \mathrm{~cm})$ of Sepharose CL-6B (Pharmacia Fine Chemicals, Inc., Piscataway, NJ, USA), was used to characterise the interaction between toxin A and human milk. $\left[{ }^{125} \mathrm{I}\right]$ toxin $\mathrm{A}(15 \mu \mathrm{g} / \mathrm{ml})$ was mixed with an equal volume of pooled human milk or Tris- $\mathrm{HCl}$ buffer and incubated for $2 \mathrm{~h}$ at room temperature; $1 \mathrm{ml}$ of the mixture was applied to the column and eluted with Tris- $\mathrm{HCl}$ buffer at room temperature. Each 1.0-ml fraction was monitored for $\gamma$ emissions. The Kav values of standard proteins (Pharmacia Fine Chemicals) was related to that of $\left[{ }^{125} \mathrm{I}\right]$ toxin A.

Native polyacrylamide gel electrophoresis. The interaction of $\left[{ }^{125} \mathrm{I}\right]$ toxin $\mathrm{A}$ with human milk was also characterised by polyacrylamide gel electrophoresis (PAGE) with a $7.5 \% \mathrm{w} / \mathrm{v}$ lower gel and an upper stacking gel. ${ }^{28}\left[{ }^{125} \mathrm{I}\right]$ toxin $\mathrm{A}(178 \mu \mathrm{g} / \mathrm{ml})$ was mixed with an equal volume of pooled human milk or Tris$\mathrm{HCl}$ buffer and incubated for $2 \mathrm{~h}$ at $4^{\circ} \mathrm{C} ; 50 \mu \mathrm{l}$ of the mixture was added to the top of the polyacrylamide gel and electrophoresis was performed at $4^{\circ} \mathrm{C}$ with a constant current of $30 \mathrm{~mA} / \mathrm{gel}$ until the tracking dye was $c .1 \mathrm{~cm}$ from the end of the gel. Gels were dried and exposed to X-OMAT AR film (Eastman Kodak, Rochester, NY, USA) at $-70^{\circ} \mathrm{C}$ for $4-6 \mathrm{~h}$ with an intensifying screen.

Neutralisation of toxin A cytotoxicity. Pooled human milk was examined for its ability to neutralise the cytotoxic activity of toxin $\mathrm{A}$ in a HeLa cell tissue culture assay. Toxin A was diluted in Tris- $\mathrm{HCl}$ buffer to a concentration four-fold greater than the highest dilution that caused complete rounding of $100 \%$ of the HeLa cells in a microtitration well $\left(\mathrm{TCD}_{100}\right)$. The $\mathrm{TCD}_{100}$ for toxin A was $150 \mathrm{ng}$ of protein. The diluted toxin A was mixed with an equal volume of pooled human milk or Tris- $\mathrm{HCl}$ buffer. After incubation at room temperature for $2 \mathrm{~h}, 50 \mu \mathrm{l}$ of each mixture was added to a microtitration well containing a monolayer of HeLa cells and $200 \mu \mathrm{l}$ of cell culture medium. The HeLa cells were prepared as described previously. ${ }^{25} \mathrm{At}$ 24 and $48 \mathrm{~h}$ after exposure to toxin, each well was examined for evidence of cytotoxicity (increased refractility, change in morphology, or partial loss of adherence).

Neutralisation of hamster lethality. Adult golden Syrian hamsters (Sasco, Omaha, NE, USA) were housed individually in a conventional animal room and fed Purina Laboratory Rodent Chow 5001 (Ralston Purina, Richmond, IN, USA) and water ad libitum. (These investigations were approved by the Texas Tech University Health Sciences Center Animal Care and Use Committee.)

Human milk was tested for protection of adult hamsters against intragastric challenge with toxin $A$ as follows. A lethal dose of toxin A $(100 \mu \mathrm{g} / \mathrm{ml})$ was mixed with an equal volume of undiluted pooled human milk or $50 \mathrm{~mm}$ phosphate buffered saline (PBS), $\mathrm{pH} 7 \cdot 2$, and incubated at room temperature for $2 \mathrm{~h}$ before intragastric inoculation $(1 \mathrm{ml} / 100 \mathrm{~g}$ body weight) of adult hamsters. Hamsters were not per- mitted to feed for $12 \mathrm{~h}$ before challenge with toxin A. Stomach acidity was neutralised with $1 \mathrm{M}$ carbonate buffer $(1 \mathrm{ml} / 100 \mathrm{~g}$ of body weight) administered orogastrically immediately before toxin A challenge, and drinking water was withdrawn $4 \mathrm{~h}$ before $\mathrm{NaHCO}_{3}$ treatment. After treatment, hamsters were observed every $8 \mathrm{~h}$ for evidence of diarrhoea or moribund condition. Moribund animals were killed immediately.

\section{Thiophilic chromatography removal of immunoglobulins in human milk}

A thiophilic adsorbent column (divinyl sulphoneactivated agarose) was used to separate the nonimmunoglobulin from the immunoglobulin fractions of human milk according to the manufacturer's instructions (T-Gel Purification Kit; Pierce, Rockford, IL, USA). Briefly, $1 \mathrm{ml}$ of pooled human milk was added to $87 \mathrm{mg}$ of $\mathrm{K}_{2} \mathrm{SO}_{4}$. The sample was loaded on to a 3-ml column of T-Gel adsorbent and washed with T-Gel binding buffer $\left(0.5 \mathrm{M} \mathrm{K}_{2} \mathrm{SO}_{4}, 50 \mathrm{mM} \mathrm{Na}_{2} \mathrm{PO}_{4}\right.$ and sodium azide $0.05 \% \mathrm{w} / \mathrm{v}, \mathrm{pH} 8.0$ ) at room temperature. The unbound eluate was recirculated three times through the column to further deplete it of residual immunoglobulin. The specifically bound material was eluted with T-Gel elution buffer ( $50 \mathrm{mM} \mathrm{Na}_{2} \mathrm{PO}_{4}$ and sodium azide $0.05 \% \mathrm{w} / \mathrm{v}, \mathrm{pH} 8.0$ ). Fractions $(2 \mathrm{ml})$ of the unbound (immunoglobulin-depleted human milk) and bound (isolated immunoglobulins from human milk) eluates were monitored for absorbance at $280 \mathrm{~nm}$. The unbound and bound fractions were pooled, dialysed against Tris- $\mathrm{HCl}$ buffer and concentrated to the starting volume by ultrafiltration with a $10-\mathrm{kDa}$ cut-off membrane filter.

\section{Quantitation of human immunoglobulin}

Quantitation of human immunoglobulins in the pooled milk and in the bound and unbound fractions from the thiophilic adsorption gel was performed by single radial immunodiffusion (RID) in plates prepared by the Binding Site (San Diego, CA, USA) which were specific for IgA, IgM and IgG. ${ }^{29}$ Known concentrations of human immunoglobulins were used to produce linear calibration curves. The immunoglobulin concentrations in the milk samples were determined from the calibration curves.

\section{SDS-PAGE of milk samples}

Samples to be analysed by SDS-PAGE were diluted with an equal volume of $0.25 \mathrm{M}$ Tris buffer, $\mathrm{pH} 6.8$, containing SDS $4 \% \mathrm{w} / \mathrm{v}$ and 2-mercaptoethanol $10 \% \mathrm{v} / \mathrm{v}$. The samples were heated at $100^{\circ} \mathrm{C}$ for $5 \mathrm{~min}$ and centrifuged at $13000 \mathrm{~g}$ for $1 \mathrm{~min}$. The supernates were then subjected to SDS-PAGE with a $7.5 \% \mathrm{w} / \mathrm{v}$ lower gel and an upper stacking gel $1.5 \mathrm{~mm}$ thick, essentially as described by Laemmli. ${ }^{30}$ After electrophoresis, the gels were fixed and stained with Coomassie Brilliant Blue as described previously. ${ }^{31}$ 


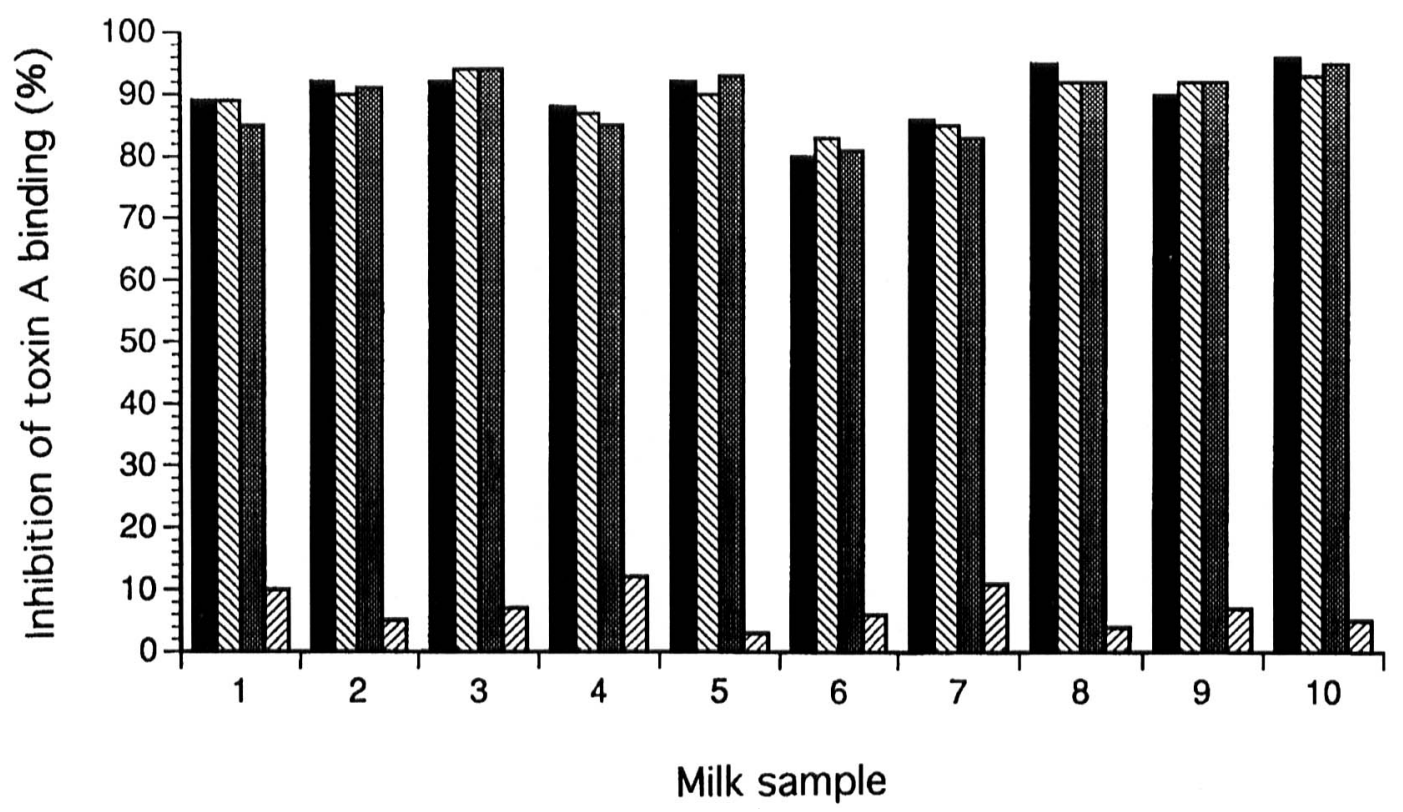

Fig. 1. Effect of human milk on $\left[{ }^{125} \mathrm{I}\right]$ toxin $\mathrm{A}$ binding to the BBM receptor: untreated milk ( $\left.\boldsymbol{\sigma}\right)$; milk heated at $100^{\circ} \mathrm{C}$ for 5 min before addition of toxin $\mathrm{A}(\mathbb{\mathbb { S }})$; milk dialysed against Tris- $\mathrm{HCl}$ buffer before addition of toxin $\mathrm{A}$ (圆); milk added to a microtitration well containing BBM receptor, incubated and washed before addition of toxin A to the well $(Z)$. Each bar represents the mean of three experiments. SDs were $<10 \%$ of the mean.

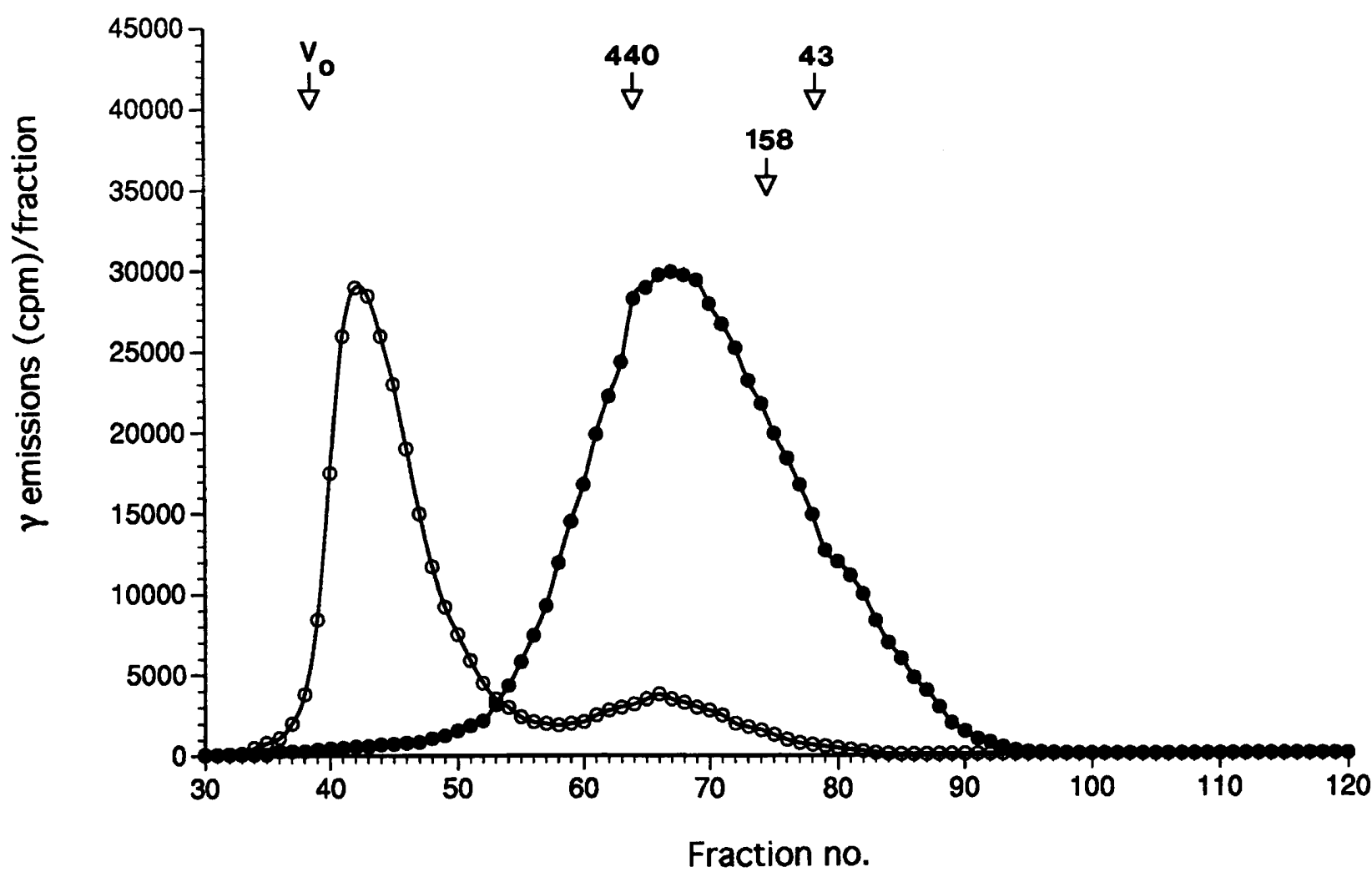

Fig. 2. Gel filtration analysis of $\left[{ }^{125} \mathrm{I}\right]$ toxin A-receptor interaction. $\left[{ }^{125} \mathrm{I}\right]$ toxin $\mathrm{A}$ was mixed with pooled human milk $(\mathrm{O}-\mathrm{O})$ or $\mathrm{Tris}-\mathrm{HCl}$ buffer (-) and incubated for $2 \mathrm{~h}$ at room temperature, and separated on a Sepharose CL-6B column eluted with Tris-HCl buffer. Arrows indicate the approximate migration of mol. wt $(\mathrm{kDa})$ markers. Vo, void volume $(\geqslant 1000 \mathrm{kDa})$.

Mol. wts were estimated by comparison to known mol. wt markers (BioRad Laboratories).

\section{Autoradiography of toxin A-milk interactions}

The SDS-PAGE-separated preparations of human milk were transferred electrophoretically to nitrocel- lulose membranes (Hoefer Scientific Instruments, San Francisco, CA, USA; $0.45 \mu \mathrm{m}$ pore size) essentially by the procedure of Towbin. ${ }^{32}$ After transfer, the membranes were rinsed in PBS, blocked with bovine serum albumin (BSA) $3 \% \mathrm{w} / \mathrm{v}$ and newborn calf serum $1 \%$ $\mathrm{v} / \mathrm{v}$ and overlaid with $\left[{ }^{125} \mathrm{I}\right]$ toxin $A .{ }^{27}$ The membranes were then washed and dried at room temperature. 
Autoradiography was performed by exposing the nitrocellulose membranes to X-OMAT AR film at $-70^{\circ} \mathrm{C}$ for $18-24 \mathrm{~h}$ with an intensifying screen.

\section{Protein determination}

Protein content was determined by the method of Lowry et al..$^{33}$ with BSA as the standard.

\section{Results}

\section{Inhibition of toxin $A$ binding by milk}

The cell-free aqueous phases of 10 human milk samples inhibited the binding of toxin A to the purified BBM receptor by an average of $90 \%$ (range : 80-96\%) (fig. 1). In the absence of milk, $1 \mathrm{ng}$ of purified BBM receptor bound $c .12 \mathrm{pg}$ of radiolabelled toxin $\mathrm{A}$. Heating $\left(100^{\circ} \mathrm{C}\right.$ for $\left.5 \mathrm{~min}\right)$ and dialysis $(8-10-\mathrm{kDa}$ cut-off) did not significantly alter the inhibitory activity in any of the milk samples. Pre-incubation of the BBM receptor with human milk had minimal effect on toxin A binding as long as the milk was removed by washing

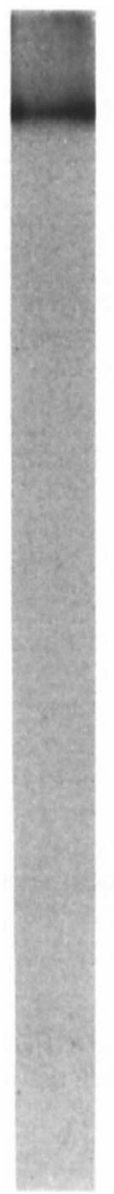

A

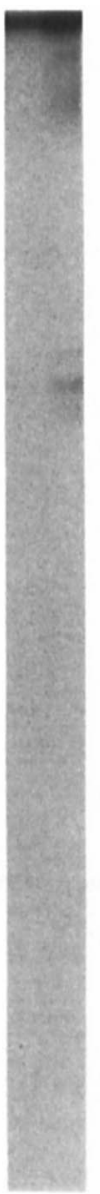

B

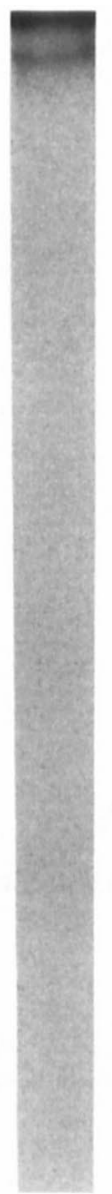

C

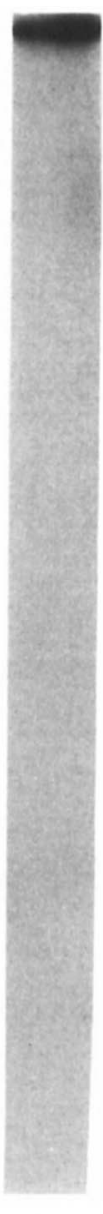

D
Fig. 3. Autoradiograph of native PAGE analysis of toxin A interaction with human milk. $\left[{ }^{125} \mathrm{I}\right]$ toxin $\mathrm{A}$ was mixed with an equal volume of Tris- $\mathrm{HCl}$ buffer (lane A), pooled human milk (B), nonimmunoglobulin fraction of human milk (C) or immunoglobulin fraction of human milk (D) and incubated for $2 \mathrm{~h}$ at $4^{\circ} \mathrm{C}$ before PAGE. before addition of $\left.{ }^{125} \mathrm{I}\right]$ toxin $\mathrm{A}$, indicating that inhibition of toxin A binding was due to the interaction of milk with toxin A and not the BBM receptor.

\section{Characterisation of the inhibitory activity}

The cell-free aqueous phase preparations from the 10 milk samples were pooled for further characterisation. Ultrafiltration through a $100-\mathrm{kDa}$ cut-off membrane filter demonstrated that the aqueous material with a mol. wt $>100 \mathrm{kDa}$ completely inhibited toxin A binding whereas material with a mol. wt $<100 \mathrm{kDa}$ had no effect on binding of toxin A.

The interaction of $\left[{ }^{125} \mathrm{I}\right]$ toxin $\mathrm{A}$ with human milk was investigated by gel filtration and native PAGE to characterise the mechanism of toxin A binding inhibition. Fig. 2 shows that $\left.{ }^{[25} \Gamma\right]$ toxin A by itself has a mol. wt of $c .300 \mathrm{kDa}$ as determined by gel filtration. This agrees closely with the published mol. wt of $308 \mathrm{kDa}$ for toxin A. ${ }^{34}$ However, when $\left[{ }^{125} \mathrm{I}\right]$ toxin A was mixed with pooled human milk, incubated for $2 \mathrm{~h}$ at room temperature and separated on a Sepharose CL-6B column, the mol. wt of $\left[{ }^{125} \mathrm{I}\right]$ toxin $\mathrm{A}$ increased to $c .600 \mathrm{kDa}$. These data suggest that the factors present in human milk which inhibit toxin A binding are complexing with the toxin rather than breaking the toxin into inactive subunits. However, it is also possible that human milk is causing toxin A to complex with itself under these conditions.

The complexing of toxin A with factors present in human milk was further substantiated by native PAGE analyses. [ $\left.{ }^{125} \mathrm{I}\right]$ toxin $\mathrm{A}$ by itself migrated $c .1 \mathrm{~cm}$ into an acrylamide $7.5 \% \mathrm{w} / \mathrm{v}$ gel during electrophoresis (fig. 3, lane A). However, $\left[{ }^{125} \mathrm{I}\right]$ toxin A remained close to the top of the gel when mixed with pooled human milk and incubated for $2 \mathrm{~h}$ at room temperature before electrophoresis in an acrylamide $7.5 \% \mathrm{w} / \mathrm{v}$ gel (fig. 3, lane B).

To better characterise the factors in human milk complexing with toxin $\mathrm{A}$, the binding of $\left.{ }^{125} \mathrm{I}\right]$ toxin $\mathrm{A}$ to transblots of electrophoretically separated components of human milk was investigated. In these experiments, pooled human milk was separated by SDS-PAGE under reducing conditions. One gel was stained with Coomassie Brilliant Blue whereas the separated proteins on the other gel were transferred to nitrocellulose and probed with $\left[{ }^{125} \mathrm{I}\right]$ toxin $\mathrm{A}$ before visualisation by autoradiography. Fig. 4 (lane B) shows that there were at least four distinct bands from human milk that specifically bound $\left[{ }^{125} \mathrm{I}\right]$ toxin $\mathrm{A}$. These bands corresponded to mol. wts of $c$. $>200,112,71$ and $56 \mathrm{kDa}$. None of these toxin A binding bands could be associated with dominant protein bands on the corresponding gel (fig. 4, lane A) suggesting that carbohydrate moieties play a dominant role in binding toxin $\mathrm{A}$.

\section{Inhibition of toxin A biological activity by human milk}

The effect of pooled human milk on the biological activity of toxin $\mathrm{A}$ in the adult hamster and in tissue 


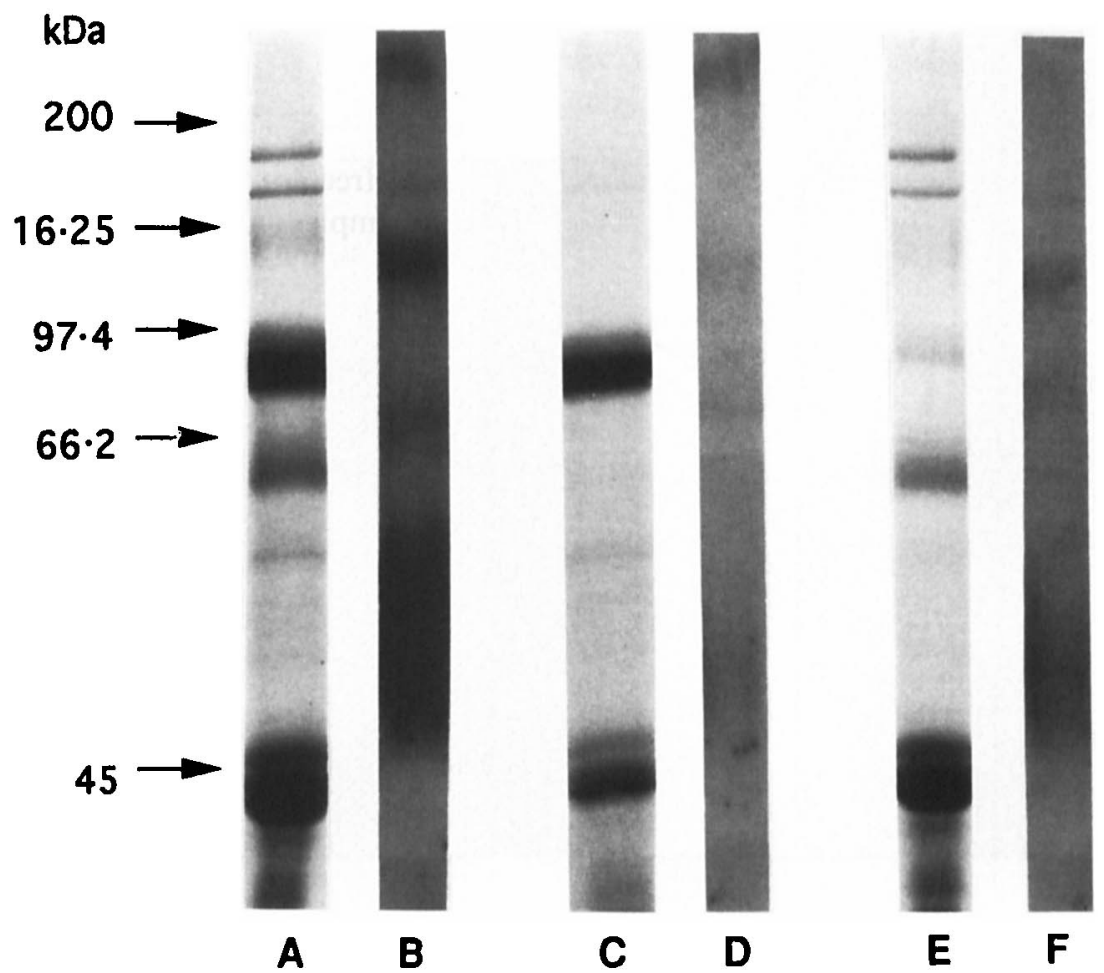

Fig. 4. SDS-PAGE and ligand blot analysis of human milk. Pooled human milk (lanes A and B), non-immunoglobulin fraction of human milk (C and D) and immunoglobulin fraction of human milk ( $\mathbf{E}$ and $\mathbf{F}$ ) were separated by SDS-PAGE under reducing conditions. One gel was stained for protein (Lanes $\mathbf{A}, \mathbf{C}$ and $\mathbf{E}$ ); the other gel was transferred to nitrocellulose and probed with [ $\left.{ }^{125} \mathrm{I}\right]$ toxin $\mathbf{A}$ before visualisation by autoradiography (B, D and F). Arrows indicate the migration of mol. wt markers.

culture was also tested. All 10 hamsters that received a lethal dose of toxin A ( $50 \mu \mathrm{g} / 100 \mathrm{~g}$ body weight) died within $48 \mathrm{~h}$ of intragastric challenge; $60 \%$ of these hamsters had evidence of diarrhoea at the time of death while the remaining $40 \%$ had no diarrhoea. However, all the dead animals had evidence of ileocaecitis (i.e., caeca that were enlarged, fluid filled and haemorrhagic). Only one (7\%) of 15 hamsters died when the same final dose of toxin A was mixed with human milk and incubated for $2 \mathrm{~h}$ at room temperature before intragastric challenge. Interestingly, $67 \%$ of the hamsters that received the human milk-toxin A mixture developed diarrhoea within $24 \mathrm{~h}$ of intragastric challenge. However, in all instances the diarrhoea disappeared within $72 \mathrm{~h}$ after intragastric challenge.

The pooled human milk did not protect HeLa tissue culture cells against the cytotoxic activity of toxin A. Mixing a toxin A solution (150 ng/ml) with an equal volume of tissue culture medium or human milk and incubating for $2 \mathrm{~h}$ at room temperature before inoculation of the monolayers resulted in actinomorphic changes in $100 \%$ of the HeLa cells within $24 \mathrm{~h}$.

\section{Thiophilic adsorption of immunoglobulins from human milk}

Human milk was divided into immunoglobulin and non-immunoglobulin fractions by thiophilic adsorption chromatography. The bound immunoglobulin and unbound non-immunoglobulin fractions were pooled and concentrated to the original starting volume. IgA was the only immunoglobulin present in the human milk and was present at a concentration of $985 \mathrm{mg} / \mathrm{L}$. This concentration is in close agreement with the amount of $\mathrm{sIgA}$ reported to be present in human milk at $1-6$ months of lactation $;^{35}>90 \%$ of this immunoglobulin was recovered in the bound fractions of the thiophilic adsorption column whereas the unbound fractions did not contain detectable immunoglobulin. Both the unbound non-immunoglobulin T-Gel fraction of human milk and the T-Gel bound immunoglobulin fraction of human milk inhibited the binding of $\left[{ }^{125} I\right]$ toxin $A$ to the BBM receptor (fig. 5). The inhibitory activity in the nonimmunoglobulin fraction was heat stable $\left(100^{\circ} \mathrm{C}\right.$ for $5 \mathrm{~min}$ ) but heating caused c. $25 \%$ loss of inhibitory activity in the immunoglobulin fraction.

Native PAGE analysis of toxin A interaction with the bound and unbound fractions from the thiophilic adsorption column is shown in fig. 3. As was demonstrated previously with whole milk (fig. 4, lane B) the unbound (lane C) and bound (lane D) fractions complexed with toxin $\mathrm{A}$, as was evident through the apparent increase in mol. wt of $\left[{ }^{125} I\right]$ toxin $A$.

The immunoglobulin and non-immunoglobulin fractions of human milk were also characterised by SDS-PAGE and ligand blotting with $\left[{ }^{125} \mathrm{I}\right]$ toxin $\mathrm{A}$. Ligand blot analysis demonstrated that the $>200$ and 56-kDa components that bound toxin A in human 


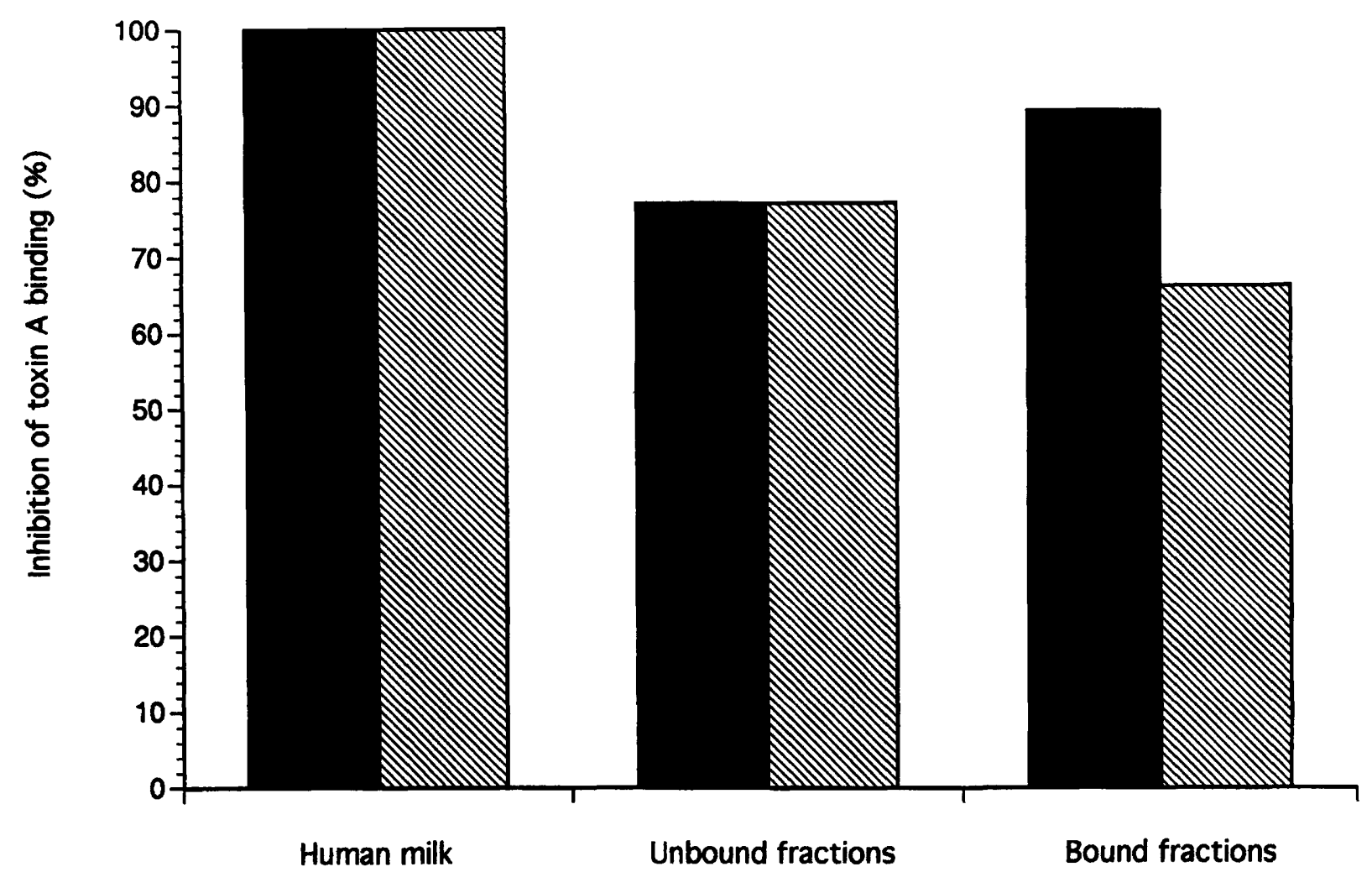

Fig. 5. Inhibition of toxin A binding to the purified BBM receptor by whole human milk and milk fractionated by thiophilic absorption; whole milk and both fractions were examined before $(\square)$ and after $(\mathbb{Q})$ heating at $100^{\circ} \mathrm{C}$ for 5 min. Each bar represents the mean of three experiments. SDs were $<10 \%$ of the mean.

milk appeared in the non-immunoglobulin fraction whereas the immunoglobulin fraction contained the 112-, 71- and 56-kDa components (fig. 4).

\section{Discussion}

Several studies have shown that human colostrum passively protects the neonatal gastrointestinal surface against enteric pathogens during the period before active development of intestinal immunity. ${ }^{13,14,36,37}$ It has been reported that breast-fed infants are less likely to be colonised with $C$. difficile than formula-fed infants. ${ }^{7,811}$ In this study, human milk inhibited the binding of toxin $A$ to a receptor purified from infant hamster brush border membranes. Binding of secreted enterotoxins to specific cell-membrane receptors are obligatory pathogenic events in diarrhoeal diseases due to enterotoxigenic bacteria. The toxin A receptor from infant hamsters was used in these investigations because of the difficulty in obtaining healthy intestinal tissue from human infants. Furthermore, the infant hamster has been used to elucidate the mechanism(s) of asymptomatic $C$. difficile intestinal colonisation ${ }^{38}$ and it has been shown that infant hamsters have an age-dependent susceptibility to asymptomatic enteric C. difficile colonisation similar to the restricted age distribution of human neonatal asymptomatic colonisation. Administration of $C$. difficile to non-antibiotic-treated infant hamsters resulted in multipli- cation of the organism in the intestinal tracts of 4-13day-old animals. These infant hamsters did not display evidence of toxicity despite toxin titres similar to the titres found in the intestinal tracts of adult hamsters with $C$. difficile-associated disease.

The purified toxin A receptor used in these investigations is a galactose- and $\mathrm{N}$-acetylglucosaminecontaining glycoconjugate that appears to be identical to the toxin A receptor reported on adult hamster and rabbit small intestine BBMs. ${ }^{26,39,40}$ This receptor involves the trisaccharide sequence Gal $\alpha 1-3 \mathrm{Gal} \beta 1$ 4GlcNAc on the reducing end of glycoconjugates. ${ }^{39,41}$ Both infant and adult BBMs have this receptor and differences in the binding kinetics of toxins A or B, or both, to this receptor do not account for the observed differences in the animals' susceptibility to $C$. difficileassociated intestinal disease. ${ }^{26}$ Several lines of evidence support the likelihood that the receptor used in the binding studies of this investigation is the physiologically functional receptor for toxin A in hamsters: (1) cell lines that produce large amounts of this trisaccharide receptor are more sensitive to toxin Ainduced cytotoxicity than are cell lines that lack detectable receptor activity; ${ }^{42}$ (2) hamsters can be protected from $C$. difficile-associated intestinal disease by immunisation with a recombinant peptide that contains the portion of toxin $\mathrm{A}$ that binds to the trisaccharide $;^{43}$ (3) monoclonal antibody that blocks specific binding of toxin A to the trisaccharide also neutralises its biological activity; ${ }^{44}$ and (4) the lectin 
produced by Bandeirea simplicifolia that binds the trisaccharide blocks the binding of toxin A to cells in culture and protects them from the cytotoxic activity of toxin $\mathrm{A}^{.45}$

The inhibitory activity present in human milk against toxin $\mathrm{A}$ binding was stable at $100^{\circ} \mathrm{C}$ for $5 \mathrm{~min}$ and restricted to compounds $>100 \mathrm{kDa}$. The significance of this inhibitory activity in vivo was demonstrated in experiments in which human milk protected adult hamsters against a lethal intragastric challenge with toxin $\mathrm{A}$. Other investigators have also demonstrated the neutralisation of toxin A in vivo by human milk or milk products. Kim et al. ${ }^{46}$ demonstrated that approximately one-third of the human colostral samples examined reduced toxin A-induced fluid accumulation in suckling mice. Lyerly et al ${ }^{47}$ showed that hamsters treated prophylactically with orally administered hyperimmune bovine IgG concentrate prepared from colostrum at parturition were protected against $C$. difficile disease. Kim et al ${ }^{25}$ demonstrated that hamsters immunised against toxins $\mathrm{A}$ and $\mathrm{B}$ are protected against clindamycin-induced $C$. difficileassociated ileocaecitis and that this protection is transferred to infant hamsters through maternal milk.

Even though human milk inhibited toxin A binding to the BBM receptor and protected hamsters against a lethal intragastric challenge with toxin $\mathrm{A}$, it did not prevent the cytotoxic activity of toxin A against HeLa tissue culture cells. However, other investigators have reported neutralisation of toxin A cytotoxic activity by human milk. For example, Wada et al. ${ }^{48}$ reported that c. $25 \%$ of colostral samples from Japanese women neutralised the cytotoxic activity of crude $C$. difficile toxins. However, no attempt was made by these investigators to examine specific neutralising activity against individual toxins A and B. Kim et al. ${ }^{46}$ reported that approximately one-third of colostral samples tested neutralised the cytopathic effect of $C$. difficile toxins $A$ and $B$. These investigators concluded that IgA played a major role in neutralisation of toxin $A$ cytotoxicity because immune precipitation of the human milk samples with anti-human IgA abolished the neutralising activity.

Human milk contains various specific antibodies and non-immunoglobulin factors that could contribute toward neutralisation of toxin A binding. Therefore, thiophilic adsorption chromatography was used to separate the immunoglobulin from the non-immunoglobulin components of human milk. The thiophilic gel is a $\beta$-mercaptoethanol derivative of divinyl sulphone-activated agarose which has been used for both the selective removal and purification of all classes of immunoglobulins from serum, ascites fluid, hybridoma cell culture media and human milk. ${ }^{49,50} \mathrm{In}$ these investigations, both the immunoglobulin and non-immunoglobulin fractions of human milk inhibited toxin A binding to the purified BBM receptor. Radial immunodiffusion indicated that IgA was the only immunoglobulin detectable in human milk and was therefore, responsible for the inhibition of binding of toxin $\mathrm{A}$ in the immunoglobulin component of human milk. Other investigators have also demonstrated inhibition of toxin A binding by IgA. Kelly et $a l .{ }^{51}$ showed that colonic aspirates containing IgA antitoxin inhibit the binding of toxin $A$ to rabbit ileal brush border membranes whereas such inhibition was not seen in the presence of colonic aspirates that did not contain IgA antitoxin.

The finding that the inhibitory activity against toxin A binding in the non-immunoglobulin fraction was heat stable and caused an apparent increase in the mol. wt of radiolabelled toxin A suggests that the inhibitory component may be a glycoconjugate toxin A receptor analogue. Recent studies have shown an array of oligosaccharides and glycoconjugates in human milk that act as receptor analogues that can inhibit the binding of certain enteric bacterial pathogens and their toxins. ${ }^{20,52-55}$ For example, receptorlike components in the non-immunoglobulin components of human milk have been shown to inhibit the action of $E$. coli and $V$. cholerae enterotoxins in vivo and in vitro. ${ }^{52,53,55-58}$ Toxin $\mathrm{A}$ binds to the carbohydrate antigens designated $\mathrm{I}, \mathrm{X}$ and $\mathrm{Y}$ which are present on the intestinal epithelium of infants and adults. ${ }^{59-62}$ These antigens are conformationally very similar to the trisaccharide sequence Gal $\alpha 1-3 \mathrm{Gal} \beta 1$ 4GlcNAc present on hamster BBMs. ${ }^{59}$ The I, $X$ and $Y$ antigens have been proposed as receptors for toxin $A$ in the human intestinal tract. Human milk is known to contain $>100$ fucosylated oligosaccharides, including the $\mathrm{X}$ antigen. ${ }^{21,23,24,63}$ Further work must be performed to determine if the $\mathrm{X}$ antigen in breast milk is inhibiting toxin A binding in these investigations. It is interesting to note that the $\mathrm{X}$ antigen also occurs on the secretory component of human antibodies. ${ }^{64}$ The secretory component has a mol. wt of $79 \mathrm{kDa}$ which is the approximate mol. wt of one of the bands in the immunoglobulin fraction of human milk which bound to toxin $\mathrm{A}$ in the ligand blotting analyses. Therefore, the neutralisation of toxin A binding in the immunoglobulin fraction of human milk may be the result of non-specific interaction of $\operatorname{sIgA}$ with toxin $\mathrm{A}$.

These data indicate that human milk may protect against $C$. difficile-induced intestinal disease in infants by inhibiting the binding of toxin $A$ to its intestinal receptor. The specific neutralisation of toxin $A$ binding by human milk would allow for the continued presence of $C$. difficile as well as toxin B in the intestine of asymptomatic infants. Both immunoglobulin and non-immunoglobulin components may be responsible for neutralisation of toxin A binding. Infant formula based on cow's milk also inhibits the binding of toxin A to the intestinal brush border membrane (unpublished observations). This could be the mechanism by which formula-fed infants are asymptomatically colonised with toxigenic $C$. difficile. In the future, detailed structural determination of the components in human and cow's milk that inhibit toxin A binding will be required. Once these protective factors are understood it may be possible to enhance not only the resistance of 
newborn infants to $C$. difficile toxins but other age groups as well.

\section{References}

1. Lyerly DM, Lockwood DE, Richardson SH, Wilkins TD. Biological activities of toxins $\mathbf{A}$ and $\mathbf{B}$ of Clostridium difficile. Infect Immun 1982; 35: 1147-1150.

2. Donta ST. Mechanism of action of Clostridium difficile toxins In: Rolfe RD, Finegold SM (eds) Clostridium difficile: its role in intestinal disease. San Diego, Academic Press, Inc. 1988 ; 169-181.

3. Lyerly DM, Wilkins TD. Purification and properties of toxins A and B of Clostridium difficile. In: Rolfe RD, Finegold SM (eds) Clostridium difficile: its role in intestinal disease. San Diego, Academic Press, Inc. 1988: 145-167.

4. Mitchell TJ, Ketley JK, Haslam SC et al. Effect of toxin A and $\mathrm{B}$ of Clostridium difficile on rabbit ileum and colon. Gut 1986; 27: 78-85.

5. Kofsky P, Rosen L, Reed J, Tolmie M, Ufberg D. Clostridium difficile - a common and costly colitis. Dis Colon Rectum 1991 ; 34 : 244-248.

6. George WL. Antimicrobial agent-associated diarrhea in adult humans. In: Rolfe RD, Finegold SM (eds) Clostridium difficile: its role in intestinal disease. San Diego, Academic Press, Inc. 1988: 31-44.

7. Cooperstock MS, Steffen E, Yolken R, Onderdonk A. Clostridium difficile in normal infants and sudden infant death syndrome: an association with infant formula feeding. Pediatrics 1982; 70: 91-95.

8. Stark PL, Lee A, Parsonage BD. Colonization of the large bowel by Clostridium difficile in healthy infants: quantitative study. Infect Immun 1982; 35: 895-899.

9. Rolfe RD. Asymptomatic intestinal colonization by Clostridium difficile. In: Rolfe RD, Finegold SM (eds) Clostridium difficile: its role in intestinal disease. San Diego, Academic Press, Inc. 1988: 201-225.

10. Qualman SJ, Petric M, Karmali MA, Smith CR, Hamilton SR. Clostridium difficile invasion and toxin circulation in fatal pediatric pseudomembranous colitis. Am J Clin Pathol $1990 ; 94: 410-416$

11. Cooperstock M. Clostridium difficile in infants and children. In: Rolfe RD, Finegold SM (eds) Clostridium difficile: its role in intestinal disease. San Diego, Academic Press, Inc. 1988: 45-64.

12. Mardh DA, Helin I, Colleen I, Oberg M, Holst E. Clostridium difficile toxin in faecal specimens of healthy children and children with diarrhoea. Acta Paediatr Scand 1982; 71: 275-278.

13. Cunningham AS, Jelliffe BD, Jelliffe EFP. Breast-feeding and health in the 1980s: a global epidemiologic review. $J$ Pediatr 1991; 118: 659-666.

14. Hanson LA, Winberg J. Breast milk and defence against infection in the newborn. Arch Dis Child 1972; 47:845-848.

15. Hayani KC, Guerrero ML, Morrow AL et al. Concentration of milk secretory immunoglobulin A against Shigella virulence plasmid-associated antigens as a predictor of symptom status in Shigella-infected breast-fed infants. $J$ Pediatr $1992 ; 121$ : 852-856.

16. Sabin AB, Fieldsteel AH. Antipoliomyelitic activity of human and bovine colostrum and milk. Pediatrics 1962; 29: 105-115.

17. Glass RI, Stoll BJ. The protective effect of human milk against diarrhea: a review of studies from Bangladesh. Acta Paediatr Scand 1989; 351 Suppl: 131-136.

18. Duffy LC, Riepenhoff-Talty M, Byers TE et al. Modulation of rotavirus enteritis during breast-feeding. Implications on alterations in the intestinal bacterial flora. Am J Dis Child 1986; 140: 1164-1168.

19. Pickering LK, Kohl S. Human milk humoral immunity and infant defense mechanism. In: Howell RR, Morriss FH, Pickering LK (eds) Human milk in infant nutrition and health. Springfield, IL, Charles C. Thomas. 1986: 123-140.

20. Laegreid A, Otnaess AB, Fuglesang J. Human and bovine milk: comparison of ganglioside composition and enterotoxininhibitory activity. Pediatr Res 1986; 20 : 416-421.
This work was supported by a Biomedical Research Seed Grant awarded to R.D.R. by Texas Tech University Health Sciences Center.

21. Grönberg G, Lipniunas P, Lundgren T, Lindh F, Nilsson B. Structural analysis of five new monosialylated oligosaccharides from human milk. Arch Biochem Biophys 1992; 296: $597-610$

22. Viverage D, Grimmonprez L, Cassanas G, Bardet L, Bonnet $H$, Soliere M. Variations of lactose and oligosaccharides in milk from women of blood types secretor $\mathrm{A}$ or $\mathrm{H}$, secretor Lewis, and secretor $\mathrm{H} /$ nonsecretor Lewis during the course of lactation. Ann Nutr Metab 1985; 29: 1-11.

23. Kobata A, Yamashita K, Tachibana Y. Oligosaccharides from human milk. Methods Enzymol 1978; 50: 216-221.

24. Egee $\mathbf{H}$, Dell A, Von Nicolai H. Fucose containing oligosaccharides from human milk. I. Separation and identification of new constituents. Arch Biochem Biophys 1983; 224: $235-253$.

25. Kim P-H, Iaconis JP, Rolfe RD. Immunization of adult hamsters against Clostridium difficile-associated ileocecitis and transfer of protection to infant hamsters. Infect Immun 1987; 55: 2984-2992.

26. Rolfe RD. Binding kinetics of Clostridium difficile toxins A and $B$ to intestinal brush border membranes from infant and adult hamsters. Infect Immun 1991; 59: 1223-1230.

27. Rolfe RD, Song W. Purification of a functional receptor for Clostridium difficile toxin A from intestinal brush border membranes of infant hamsters. Clin Infect Dis 1993; 16 Suppl 4: S219-S227.

28. Davis BJ. Disc electrophoresis. II. Methods and application to human serum proteins. Ann NY Acad Sci 1965; 121: 404-427.

29. Mancini G, Carbonara OA, Heremans JF. Immunochemical quantitation of antigens by single radial immunodiffusion. Int $J$ Immunochem 1965; 2: 235-254.

30. Laemmli UK. Cleavage of structural proteins during the assembly of the head of bacteriophage T4. Nature 1970; 227: $680-685$.

31. Rolfe RD, Finegold SM. Purification and characterization of Clostridium difficile toxin. Infect Immun 1979; 25: 191-201.

32. Towbin H, Staehelin T, Gordon J. Electrophoretic transfer of proteins from polyacrylamide gels to nitrocellulose sheets: procedure and some applications. Proc Natl Acad Sci USA 1979; 76: 4350-4354.

33. Lowry OH, Rosebrough NJ, Farr AL, Randall RJ. Protein measurement with Folin phenol reagent. J Biol Chem 1951; 193: $265-275$

34. Dove CH, Wang S-Z, Price SB et al. Molecular characterization of the Clostridium difficile toxin A gene. Infect Immun 1990; 58: $480-488$

35. Goldman AS. The immune system of human milk: antimicrobial, antiinflammatory and immunomodulating properties. Pediatr Infect Dis $J$ 1993; 12: 664-672.

36. Glass RI, Svennerholm A-M, Stoll BJ et al. Protection against cholera in breast-fed children by antibodies in breast milk. $N$ Engl J Med 1983; 308: 1389-1392.

37. Larsen SA, Homer DR. Relation of breast versus bottle feeding to hospitalization for gastroenteritis in a middle-class US population. J Pediatr 1978; 92: 417-418.

38. Rolfe RD, Iaconis JP. Intestinal colonization of infant hamsters with Clostridium difficile. Infect Immun 1983; 42: 480-486.

39. Krivan HC, Clark GF, Smith DF, Wilkins TD. Cell surface binding site for Clostridium difficile enterotoxin: evidence for a glycoconjugate containing the sequence Gal $\alpha 1$ 3Gal $\beta 1-4 G l c N A c$. Infect Immun 1986; 53: 573-581.

40. Pothoulakis C, LaMont JT, Eglow $\mathbf{R}$ et al. Characterization of rabbit ileal receptors for Clostridium difficile toxin $\mathbf{A}$. Evidence for a receptor-coupled $\mathrm{G}$ protein. $J$ Clin Invest 1991 ; 88: 119-125.

41. Clark GF, Krivan HC, Wilkins TD, Smith DF. Toxin A from Clostridium difficile binds to rabbit erythrocyte glycolipids with terminal Gal $\alpha 1-3 \mathrm{Gal} \beta 1-4 \mathrm{GlcNAc}$ sequences. Arch Biochem Biophys 1987; 257: 217-229.

42. Tucker KD, Carrig PE, Wilkins TD. Toxin A of Clostridium difficile is a potent cytotoxin. J Clin Microbiol 1990; 28: 869-871. 
43. Lyerly DM, Johnson JL, Frey SM, Wilkins TD. Vaccination against lethal Clostridium difficile enterocolitis with a nontoxic recombinant peptide of toxin A. Curr Microbiol $1990 ; 21: 29-32$.

44. Frey SM, Wilkins TD. Localization of two epitopes recognized by monoclonal antibody PCG-4 on Clostridium difficile toxin A. Infect Immun 1992; 60: 2488-2492.

45. Wilkins TD, Tucker KD. Clostridium difficile toxin A (enterotoxin) uses Gal $\alpha 1-3 \mathrm{Gal} \beta 1-4 \mathrm{GlcNAc}$ as a functional receptor. Microecol Ther 1989; 19: 225-227.

46. Kim K, Pickering LK, DuPont HL, Sullivan N, Wilkins T. In vitro and in vivo neutralizing activity of human colostrum and milk against purified toxins A and B of Clostridium difficile. J Infect Dis 1984; 150: 57-62.

47. Lyerly DM, Bostwick EF, Binion SB, Wilkins TD. Passive immunization of hamsters against disease caused by Clostridium difficile by use of bovine immunoglobulin $\mathrm{G}$ concentrate. Infect Immun 1991; 59: 2215-2218.

48. Wada $\mathrm{N}$, Nishida $\mathrm{N}$, Iwaki $\mathrm{S}$ et al. Neutralizing activity against Clostridium difficile toxin in the supernatants of cultured colostral cells. Infect Immun 1980; 29: 545-550.

49. Hutchens TW, Magnuson JS, Yip T-T. Secretory IgA, IgG, and IgM immunoglobulins isolated simultaneously from colostral whey by selective thiophilic adsorption. $J$ Immunol Methods 1990; 128: 89-99.

50. Porath J, Maisano F, Belew M. Thiophilic adsorption-a new method for protein fractionation. FEBS Lett $1985 ; 185$ : 306-310.

51. Kelly CP, Pothoulakis C, Orellana J, LaMont JT. Human colonic aspirates containing immunoglobulin $\mathrm{A}$ antibody to Clostridium difficile toxin A inhibit toxin A-receptor binding. Gastroenterology 1992; 102: 35-40.

52. Laegreid A, Kolsto Otnaess AB. Trace amounts of ganglioside GM1 in human milk inhibit enterotoxins from Vibrio cholerae and Escherichia coli. Life Sci 1987; 40: 55-62.

53. Newburg DS, Pickering LK, McCluer RH, Cleary TG. Fucosylated oligosaccharides of human milk protect suckling mice from heat-stable enterotoxin of Escherichia coli. $J$ Infect Dis 1990; 162: 1075-1080.
54. Hanson LA, Ahlstedt S, Andersson B et al. Protective factors in milk and the development of the immune system. Pediatrics 1985; 75: 172-176.

55. Cleary TG, Chambers JP, Pickering LK. Protection of suckling mice from heat-stable enterotoxin of Escherichia coli by infant formulas. J Pediatr Gastroenterol Nutr 1985; 4: 125-127.

56. Holmgren J, Svennerholm A-M, Åhrén C. Nonimmunoglobulin fraction of human milk inhibits bacterial adhesion (hemagglutination) and enterotoxin binding of Escherichia coli and Vibrio cholerae. Infect Immun 1981; 33: 136-141.

57. Otnaess A-B, Svennerholm A-M. Non-immunoglobulin fraction of human milk protects rabbits against enterotoxininduced intestinal fluid secretion. Infect Immun 1982; 35: 738-740.

58. Otnaess A-B, Laegreid A, Ertresvåg K. Inhibition of enterotoxin from Escherichia coli and Vibrio cholerae by gangliosides from human milk. Infect Immun 1983; 40: 563-569.

59. Tucker KD, Wilkins TD. Toxin A of Clostridium difficile binds to the human carbohydrate antigens $\mathrm{I}, \mathrm{X}$, and $\mathrm{Y}$. Infect Immun 1991; 59: 73-78.

60. Holgersson J, Stromberg N, Breimer ME. Glycolipids of human large intestine: difference in glycolipid expression related to anatomical localization, epithelial/non-epithelial tissue and the $\mathrm{ABO}, \mathrm{Le}$ and Se phenotypes of the donors. Biochimie 1988; 70: 1565-1574.

61. McKibbin JM, Spencer WA, Smith EL et al. Lewis blood group fucolipids and their isomers from human and canine intestine. J Biol Chem 1982; 257: 755-760.

62. Sakamoto J, Furukawa K, Cordon-Cardo C et al. Expression of Lewis $^{\mathrm{a}}$, Lewis ${ }^{\mathrm{b}}, \mathrm{X}$, and $\mathrm{Y}$ blood group antigens in human colonic tumors and normal tissue and in human tumorderived cell lines. Cancer Res 1986; 46: 1553-1561.

63. Brassart D, Woltz A, Golliard M, Neeser J-R. In vitro inhibition of adhesion of Candida albicans clinical isolates to human buccal epithelial cells by Fuc $\alpha 1->2 \mathrm{Gal} \beta$-bearing complex carbohydrates. Infect Immun 1991; 59: 1605-1613.

64. Mizoguchi AT, Mizuochi T, Kobata A. Structures of the carbohydrate moieties of secretory component purified from human milk. J Biol Chem 1982; 257: 9612-9621. 